\title{
УДK: 613.6+616-057:001.5
}

\section{БИОЛОГИНЕСКИЕ АГЕНТЫ КАК ФАКТОРЫ ПРОФЕССИОНААЬНОГО РИСКА}

Шапко В.Г., Стерен6оген М.Ю., Чуановеu A.9.

\section{Институт меАишины труда АМН Украины, г. Киев}

Представлены данные анализа собственных исследований, отечественной и зарубежной литературы, посвященной оценке уровня потенциальной опасности для работающих с биологическим материалом - микроорганизмами, вирусами, простейшими, микробами-продуцентами. Рассмотрены вопросы систематизации и классификации биологических факторов, предложены пути оценки риска биологических факторов для здоровья работающих.

Ключевые слова: биологический агент, риск, классификации биологических агентов

В научной литературе накоплен большой опыт по гигиенической оценке условий труда на предприятиях и объектах, производящих и использующих биологические препараты в различных отраслях промышленности и сельского хозяйства $[5,6,14$, $22,24,26,27,33,35,37,39,41,42]$. Вместе с тем, слабо разработан вопрос об определении уровней потенциальной опасности для работающих с биологическим материалом (БМ), т.е. с теми биологическими агентами - микроорганизмами, вирусами, простейшими и т.д., которые в воздухе производственных помещений, как правило, не нормированы. Специалистами многих стран широко обсуждаются методические подходы к нормированию этих веществ в воздухе рабочей зоны $[2,23,25,34,38$, 44]. Вопросам влияния биологического фактора посвящена Директива 2000/54/ЕС от 18.09.2000 г. о защите работников от опасностей, связанных с влиянием биологических агентов на производстве. По определению этой Директивы «биологическим материалом» считаются микроорганизмы, в том числе генетически измененные, культуры клеток и внутренние паразиты (эндопаразиты), способные вызывать у человека какую-либо инфекцию, аллергическое состояние или отравление. В Украине действует ГОСТ 12.1.008-76 ССБТ «Биологическая безопасность. Общие требования», который включает понятия биологической опасности, связанной с животными, растениями, человеком и продуктами их жизнедеятельности.

Директива предусматривает распределение БМ в соответствии со степенью его опасности на четыре группы. К первой относятся биологические агенты, не способные повлечь заболевания человека; ко второй - способные повлечь заболевания человека, однако не способные переносить инфекцию (профилактические и лечебные средства имеются); к третьей - способные повлечь опасные заболева- ния и переносить инфекцию (эффективные профилактические и лечебные средства имеются); к четвертой - способные повлечь опасные заболевания и составляющие большую опасность для работающих и общества, в целом быстро распространяющиеся (эффективные средства профилактики и лечения, как правило, отсутствуют).

Қлассификация БМ, которой пользуются на УКраине, в основном, построена на тех же принципах, и в ней также четыре группы, распределенные по патогенности. Однако в ней, в отличие от европейской, особо опасные БМ отнесены к первой группе, а неопасные - к четвертой. БМ четвертой группы, которые соответствуют первой по Директиве, в Украине не считаются абсолютно безвредными, поскольку в определенных условиях (большая концентрация, ослабленный иммунитет и т.п.) они способны нанести вред человеку [16].

При работе с инфекционными агентами специалисты руководствуются документом «Державні санітарні правила ДСП 9.9.5.03599 «Безпека роботи 3 мікроорганізмами I-II груп патогенності». Однако риск при работе с данными биологическими агентами не может быть рассчитан, в связи с отсутствием подходов к расчету риска при работе с БМ (биологическими агентами). Принятая в гигиене труда концепция риска, основанная на превышении нормативов (ПДК и ОБУВ), не может, по нашему мнению, распространяться на данную группу факторов. Зависимость «доза-эффект»в этом случае не может быть использована на уровне «нулевого» риска. Должен быть установлен коэффициент запаса в зависимости от потенциальной опасности биологического агента. Для биологических агентов с установленным нормативом риск может быть рассмотрен, но он не может быть рассчитан аналогично риску действия химического вещества. 
Биологические агенты способны оказывать на организм работающих воздействия трех основных типов: сенсибилизация, инфицирование и интоксикация.

Аллергенное действие присуще органическим веществам растительного и животного происхождения, многим видам бактерий и грибов, их спорам, продуктам жизнедеятельности клещей и других насекомых и т.д. Сложность антигенных комплексов биологических агентов обусловливает развитие различных (по качеству и количеству) аллергических процессов. При контакте с биологическими агентами чаще всего возникает гиперчувствительность. В одних случаях она может проявляться в первые минуты и часы первичного или повторного контакта при значительном количестве биологического агента и протекать в виде «сенной лихорадки». При постоянном воздействии малых концентраций биологических агентов развивается гиперчувствительность замедленного типа. К тяжелым проявлениям аллергии у работающих с биологическими агентами относят экзогенные аллергические альвеолиты, этиологическими агентами которых являются: микроорганизмы - термофильные актиномицеты, грибы, простейшие, грамотрицательные бактерии; биологически активные субстанции животного и растительного происхождения (протеины, глико- и липопротеины, полисахариды, ферменты). Аллергия, вызванная биологическими агентами, может быть поливалентной и нередко сохраняется до 5 лет после прекращения работ с биологическими факторами: первыми исчезают поражения кожных покровов, затем - дыхательных путей [1-3].

Инфекционное действие возможно при попадании в организм рабочих бактериальной и вирусной флоры, грибов и их спор. К профессиональным контингентам, подвергающимся риску заражения возбудителями зоонозов, кроме работников сельского хозяйства, можно отнести рабочих мясо- и птицекомбинатов, рабочих предприятий по переработке пищевых продуктов и промышленного сырья животного и растительного происхождения.

В особую группу профессиональных заболеваний следует выделить микозы - заболевания, вызываемые грибами. Микозы чаще возникают при иммунодепрессии, нарушении обменных процессов, продолжительном воздействии антибиотиков, диабете, туберкулезе. Во время перерывов в работе воспалительные процессы, главным образом на кожных покровах и слизистых оболочках, заметно уменьшаются, патологический процесс приобретает затяжное течение. Респираторные микозы чаще встречаются, чем диагностируются [5, 6, 17-19, 27].

Токсическое действие биологических агентов на организм работающих является результатом присущей бактериям и грибам способности к образованию токсинов. Грамотрицательные бактерии продуцируют эндотоксины, а грибы - микотоксины. Вопросы токсинообразования широко освещены в отечественной и зарубежной литературе [21, 31, 32]. Вместе с тем, следует отметить, что практически во всех случаях биологические агенты воздействуют на организм рабочих не изолированно, а в сочетании с факторами физической и химической природы. Однако научные данные о комбинированном действии этих факторов малочисленны [12, 13]. А.А.Кучуком и др. был проведен многофакторный стратификационный анализ данных ретроспективного изучения состояния здоровья лиц основных профессий ферментного производства и условий труда, определен высокий относительный риск развития изменений при сочетанном воздействии пыли ферментных препаратов и микробной обсемененности воздуха рабочей зоны [15].

Значительную долю среди загрязнителей биологической природы составляют микроорганизмыпродуценты и готовые формы препаратов, содержащие живые клетки и споры. Современные биотехнологии на основе микробного синтеза могут представлять экологическую опасность, хотя в качестве микроорганизмов-продуцентов применяют только непатогенные нетоксичные штаммы. [2, 4 , $7,9,10,26,27]$. Из числа контаминантов окружающей среды наиболее опасными для человека можно считать кормовые белки, являющиеся сильными аллергенами. Остальные вредные эффекты кормовых белков (иммуномодулирующее действие, активация комплемента и биогенных аминов) менее выражены, в связи с чем санитарный стандарт на них устанавливается по сенсибилизирующему действию, а величина его выражается в миллиграммах белка, который в воздухе определяют неспецифическим методом без учета его антигенной структуры. Менее опасными являются продукты микробиологического синтеза: аминокислоты, ферменты, витамины, полисахариды. Методика регламентирования разработана только для ферментов [10].

Научные данные о биологических факторах по мере накопления систематизировались в виде клас- 
сификаций. Қак правило, в них использовались отдельные свойства БМ. Так, гигиеническая классификация базируется на критериальных оценках опасности по ПДК, микробиологическая - на свойствах микроорганизмов вызывать сенсибилизацию или инфекционное заболевание и др. Вместе с тем, эти классификации не учитывают результатов гигиенических, клинических, эпидемиологических и других исследований, полученных в последние годы. Опубликованы также новые данные о наличии специфических эффектов у ряда биопрепаратов гепатотоксичность, заболевания крови, генетические последствия (например, у некоторых микотоксинов) [45-48].

Из данных литературы видно, что биологические агенты не имеют однозначной классификационной основы, как, например, химические и физические факторы. Все классификации построены по монопризнаку или основной направленности действия. В связи с этим нами были проведены углубленные исследования по изучению всех возможных классификаций в мировой практике.

При оценке степени опасности биологических загрязнителей приведенные выше классификации могут быть использованы лишь в отношении микроорганизмов, в том числе простейших и вирусов (рекомбинантных, гибридных или мутантных). Что касается других биологических загрязнителей, то для них также существуют классификации.

Так, для гидролитических ферментных препаратов разработана классификация, имеющая 4 класса опасности: 1 -й класс - чрезвычайно опасные препараты, сильные аллергены, обладают выраженным раздражающим действием; 2-й - высокоопасные препараты, аллергены средней силы, обладают сильным раздражающим действием; 3 -й - умеренно опасные препараты, слабые аллергены, обладающие слабым раздражающим действием; 4-й класс малоопасные ферментные препараты [10].

Предложена также классификация, учитывающая степень опасности для промышленных микроорганизмов [30]. Согласно этой классификации, промышленные микроорганизмы также подразделяют на 4 класса опасности:

1-й класс - чрезвычайно опасные микроорганизмы, обладают выраженным общим токсическим или аллергенным действием; 2-й - высокоопасные, могут оказывать сильное аллергенное и общее токсическое действие; 3 -й - умеренно опасные, обладающие слабым общим токсическим и аллергенным действием; 4-й - малоопасные, практически не об- ладают аллергенным и общим токсическим действием.

Для оценки влияния биологических факторов на неспецифические факторы защиты организма принято использовать не менее трех показателей, отражающих функциональное состояние различных звеньев резистентности организма [1]

K наиболее информативным показателям неспецифической защиты организма, можно отнести следующие:

а) содержание лизоцима в сыворотке крови;

б) состояние кожных покровов (бактерицидность, аутофлора);

в) количественный состав микрофлоры кишечника;

г) фагоцитарная активность нейтрофилов крови.

Я.Дуткевич предложил классификацию биологических вредных факторов, которые встречаются в сельском хозяйстве по принципу «источник болезнетворного начала - эффект (заболевание)» [44]. Классификационные группы включают:

- микроорганизмы, обитающие на животных и растениях, субстанции, которые они продуцируют (токсины), и вызывающие аллергические и иммунотоксические заболевания;

- клещи (различных видов и родов), которые являются переносчиками вирусных и спирохетозных заболеваний, Herpes zoster, боррелиоз;

- субстанции растительного происхождения, вызывающие аллергические заболевания и интоксикации;

- субстанции животного происхождения (вирусы, бактерии, грибы и простейшие), вызывающие зоонозы (бруцеллез, токсоплазмоз, лептоспироз и др.);

- аллергены растительного происхождения (сельдерей, мята, лаванда и др.), вызывающие аллергическое состояние кожных покровов.

Существует еще ряд классификаций, которые относятся к вирусам, грибам, а также к их подклассам. Имеется также ряд классификаций, отражающих связь биологических факторов с профессиональными заболеваниями

Гигиенистами труда разработана «Гигиеническая классификация труда по показателям вредности и опасности факторов производственной среды, тяжести и напряженности трудового процесса» (1997), которая частично была нами дополнена в разделе «Биологические факторы» (таблица) . 
Классы условий труда в зависимости от содержания в воздухе рабочей зоны вредных веществ биологического происхождения

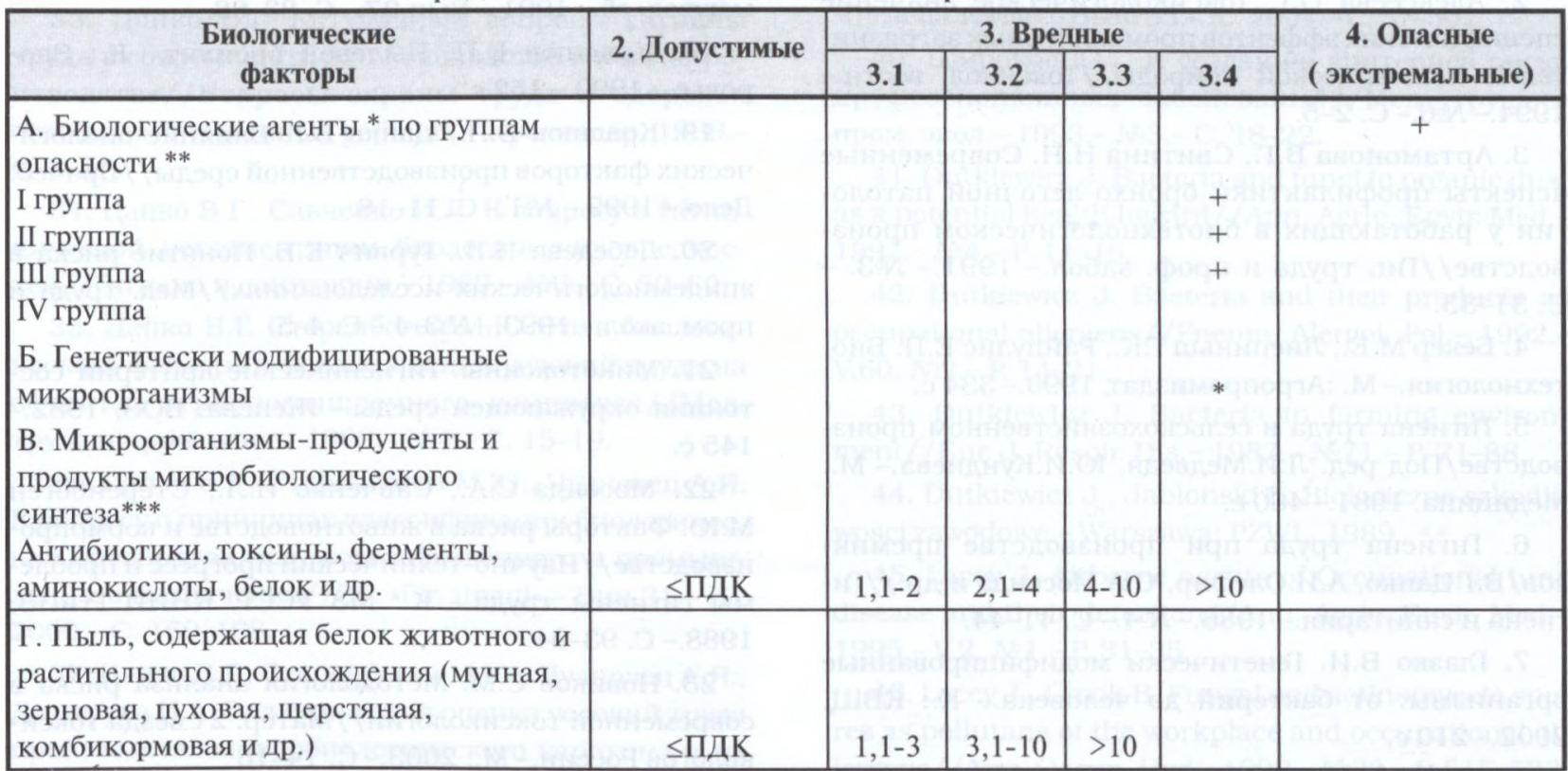

* Биологический агент - любой организм, естественный или модифицированный, который способен вызвать инфицирование, интоксикацию, аллергию или отравление.

** «Державні санітарні правила ДСП 9.9.5.03599 «Безпека роботи з мікроорганізмами I-II груп патогенності».

*** Работа в специализированных медицинских, ветеринарных учреждениях, независимо от ведомственной принадлежности и формы собственности, специализированных хозяйствах для больных животных. Виды работ, при которых возможен контакт с патогенными микроорганизмами на предприятиях кожевенной и мясной промыциленности, при осуществлении ремонта и обслуживания канализационных систем относятся к классу 3.2.

+ Независимо от концентрации фактора в воздухе рабочей зоны условия труда относятся к данному классу.

Таким образом, анализируя научные данные об условиях труда при работе с биологическими агентами различного происхождения, данные о влиянии их на организм экспериментальных животных и данные о состоянии здоровья работающих, можно заключить, что при определении риска для здоровья следует учитывать:

- вид биологического фактора;

- класс опасности;

- источник (носитель);

- пути передачи, механизм действия;

- влияние на человека (патогенез, симптомы, клиническая картина);

- профессию и характер работы;

- стаж работы, время контакта с биологическим фактором;

- меры профилактики.

Учитывая разнообразие биологических агентов, специфические особенности их действия на организм человека, а также отсутствие для многих из них гигиенических регламентов, можно предло- жить три основных подхода к оценке риска здоровью работающих:

- по критерию «доза-эффект» - для препаратов, имеющих ПДК в воздухе рабочей зоны

- безпороговое воздействие при работе с высокоопасными биологическими агентами

- потенциальный риск - при работе с неидентифицированным БМ.

\section{Выводы}

1. Обобщение и анализ данных литературы о риске здоровью работающих свидетельствуют об отсутствии единых подходов к оценке биологических факторов как с количественной, так и качественной стороны.

2. Существующие классификации отдельных групп биологических факторов недостаточны для унифицированной оценки профессионального риска для работающих.

3. Необходимо дальнейшее накопление (мониторинг) научных данных о биологических факторах, а так же совершенствование методических подходов к количественной оценке риска для человека. 


\section{Литература}

1. Адо А.Д. Аллергия.- М.: Знание, 1984.- 160 с.

2. Алексеева О.Г. Токсикологическое значение специфических эффектов промышленных загрязнителей биологической природы//Токсикол. вестн.1994.- №6.- С. 2-5.

3. Артамонова В.Г., Свитина Н.Н. Современные аспекты профилактики бронхо-легочной патологии у работающих в биотехнологическом производстве//Гиг. труда и проф. забол.- 1991.- №3. С. $31-33$.

4. Бекер М.Е., Лиепиньш Г.К., Райпулис Е.П. Биотехнология.- М. :Агропромиздат, 1990.- 334 с.

5. Гигиена труда в сельскохозяйственном производстве/Под ред. Л.И.Медведя, Ю.И.Кундиева.- М.: Медицина, 1981.- 460 с.

6. Гигиена труда при производстве премиксов/В.Г.Цапко, А.И.Олефир, С.А.Мосендз и др.//Гигиена и санитария.- 1986.- №4.- С. 41-44.

7. Глазко В.И. Генетически модифицированные организмы: от бактерий до человека.- К.: КВІЦ, 2002.- $210 \mathrm{c}$

8. ГОСТ №12.1.005-88. Общие санитарно-гигиенические требования к воздуху рабочей зоны.- М.: Изд-во стандартов, 1988.- 16 с.

9. Грачева И.М. Технология ферментных препаратов.- М.: Агропромиздат, 1987.- 335 с.

10. Гребешкова Р.Н. Использование ферментных препаратов в СССР.- М.: ОНТИТЭН микробиопром., 1982.- 9 c.

11. Диксон М., Уэбб Э. Ферменты.-В 3 т.- М.: Мир. 1982.- 1118 c.

12. Измеров Н.Ф. Капцов В.А., Денисов Э.И., Овакимов В.Г. Проблема оценки профессионального риска в медицине труда//Мед. труда и пром. экол.1993.- №3.- C. 1-8.

13. Измеров Н.Ф. Капцов В.А., Овакимов В.Г., Денисов Э.И. Концепция оценки профзаболеваний по категориям их риска и тяжести / /Мед. труда и пром. экол.- 1993.- №9-10.- С. 3-7.

14. Израйлет Л.И., Эглите М.Э., Дроздова Л.В. и др. Вопросы гигиены труда и состояние здоровья рабочих в производстве кормов//Гигиена труда и проф. забол.- 1976.- №10.- С. 43-45.

15. Иммунный статус лиц подвергшихся воздействию комбикормовой пыли/В.А.Стежка, А.А.Кучук, Н.Н.Дмитруха и др.//Гигиена и санитария.- 1991.№8.- С. 30-33.

16. Кононенко А.О., Волков В.П., Бородін В.В., Стеренбоген М.Ю. Порівняльний аналіз вимог Законодавства України та СС щодо захисту працівників від шкідливої дії біологічних матеріалів//Інф. бюл. 3 охорони праці.- 2004.- №2.- С. 5-7.
17. Краснюк Е.П. Актуальные вопросы профессиональной патологии и медицинское обслуживание работников сельского хозяйства//Гиг. труда: Респ. межвед. сб.- 1991.- Вып.27.- С. 83-88.

18. Краснюк Е.П. Пылевой бронхит.- К.: Здоровье.- $1990 .-152$ с.

19. Краснюк Е.П., Цапко В.Г. Влияние биологических факторов производственной среды/ /Врачеб. Дело.- 1999.- №1.- С. 11-18.

20. Лебедева Н.В., Гурвич Е.Б. Понятие риска в эпидемиологических исследованиях//Мед. труда и пром. экол.- 1993.- №3-4.- С. 4-5.

21. Микотоксины. Гигиенические критерии состояния окружающей среды.- Женева: ВОЗ, 1982.$145 \mathrm{c}$.

22. Мосендз С.А., Савченко И.Л., Стеренбоген М.Ю. Факторы риска в животноводстве и кормопроизводстве / /Научно-технический прогресс и проблемы гигиены труда.- К.: МЗ УССР, КНИИ ГтиПЗ, 1988.- С. 93-94.

23. Новиков С.М. Методология анализа риска в современной токсикологии / /Матер. 2 съезда токсикологов России.- М., 2003.- С. 14-16

24. Олефир А.И. Биологические вредности//Гигиена труда в сельскохозяйственном производстве/ Под ред. Л.И.Медведя, Ю.И.Кундиева.- М., 1981.С. 141-155.

25. Олефир А.И. О необходимости регламентации уровней бактериальной флоры в воздухе животноводческих помещений//Гигиена и санитария.1985.- №4.- С. 79-80.

26. Падалкин В.П., Штейнберг Г.Б. Биологический фактор производственной и окружающей среды / /Руководство по гигиене труда/Под ред. Н.Ф.Измерова.- М.: Медицина, 1987.- Т.2.- С. 263-275.

27. Пивоваров Ю.П., Королик В.В. Промышленные микроорганизмы - причина возможного негативного действия на окружающую среду и здоровье человека/ /Токсикол. вестн.- 1994.- №6.- С. 13-16.

28. Просверницын С.А. Влияние производственной пыли комбикормовых заводов на органы дыхания человека и животных: Автореф. дисс. ... к.м.н.Л., 1979.- 15 с.

29. Профессиональные заболевания работников сельского хозяйства/Под ред. Ю.И.Кундиева, Е.П.Краснюк.- 2-е изд., перераб. и доп.- К.: Здоров'я, 1989.- 273 с.

30. Трахтенберг И.М., Тимофиевская Л.А., Квятковская И.Я. Методы изучения хронического действия химических и биологических загрязнителей.Рига: Зинатне, 1987.- 172 с.

31. Тутельян В.А., Кравченко Л.В. Микотоксины.М.: Медицина, 1985.-289 с. 
32. Тутельян В.А. Природные токсины и проблемы биобезопасности//Матер. 2 съезда токсикологов России.- М., 2002.- С. 115-116.

33. Цапко В.Г. Актуальные вопросы гигиены труда в современном животноводстве и кормопроизводстве//Вопросы охраны труда и здоровья сельскохозяйственных рабочих.- Краснодар, 1986.C. 8-10.

34. Цапко В.Г., Савченко И.Л. К вопросу о гигиенической регламентации биологических вредностей / / Гигиена и санитария.- 1989.- №6.- С. 59-60.

35. Цапко В.Г, Стеренбоген М.Ю. Роль биологического фактора в формировании условий труда на объектах агропромышленного комплекса//Мед. труда и пром. экол.- 1999.- №4.- С. 15-19.

36. Цапко В.Г., Стеренбоген М.Ю., Чудновец А.Я. К вопросу о принципах классификации биологических препаратов сельскохозяйственного и промышленного назначения//3б. "Гіг. праці".- Вип.31.- К., 2000.- C. 159-168.

37. Цапко В.Г., Стеренбоген М.Ю., Чудновец А.Я., Дмитруха Н.А. Гигиеническая оценка условий труда производства микробиологического каротина и их влияние на здоровье работающих//Зб. "Гіг. праці".Вип.33.- К., 2002.- С. 20-24.

38. Цапко В.Г., Стеренбоген М.Ю., Чудновец А.Я. Итоги научных исследований и приоритетные направления в области гигиенической оценки биологических факторов//Сб. "Гигиена труда".- Вып.34, т. 1.- К., 2003.- C. 54-66.
39. Цапко В.Г., Стеренбоген М.Ю., Чудновец А.Я. Условия труда и здоровье рабочих на производстве с биотехнологиями на основе микробного синтеза/ /Сб. "Гигиена труда».- Вып. 35.-К., 2004.- С. 37-50.

40. Широков Ю.Г. К созданию критериев риска профессиональных заболеваний//Мед. труда и пром. экол.- 1993.- №3.- С. 18-22.

41. Dutkiewicz J. Bacteria and fungi in organic dust as a potential health hazard//Ann. Agric. Envir. Med.1997.- №4.- P. 11-16.

42. Dutkiewicz J. Bacteria and their products as occupational allergens//Pneum. Alergol. Pol.- 1992.V.60, №2.- P. 14-21.

43. Dutkiewicz J. Bacteria in farming environment//Eur. J. Respir. Dis.- 1987.- №71.- P. 71-88.

44. Dutkiewicz J., Jablonski L. Biologiczne szkodliwosci zawodowe.-Warszawa: PZWL, 1989.

45. Lacey J. Airborne agents of Occupational lung disease and their detection//Ann. Agric. Envir. Med.1995.- V.2, №1.- P. 31-35.

46. Lacey J., Crook B. Fungal and actinomycete spores as pollutans of the workplace and occupational allergens / / Ann. Occup. Hyg.- 1998.- №32.- P. 515-533.

47. Lacey J., Dutkiewicz J. Bioaerosols and occupational lung disease//J. Aerosol Sci.- 1994.- V.25, №8.P. 1371-1404.

48. Sorenson W.G. Mycotoxins as potential occupational hazards//Develop. Ind. Microb.- 1990.- V.31.P. 205-211.

\section{БІОЛОГІЧнІ АГЕНТИ ЯК ЧИНнИКИ ПРОФЕСІЙНОГО РИЗИКУ}

\section{Шапко В.Г., Стеренбоген М.Ю., Чуановешь А.я.}

\section{Інститут меАишини праші АМН України, м.Київ}

Наведено аналіз вітчизняної і зарубіжної літератури, присвяченій оцінці рівня потенційної небезпеки для тих, хто працює з біологічним матеріалом - мікроорганізмами, вірусами, найпростішими, мікробами-продуцентами. Розглянуто питання систематизації і класифікації біологічних чинників, запропоновано шляхи оцінки ризику біологічних чинників для здоров'я робітників.

Ключові слова: біологічний фактор, ризик, класифікація біологічних агентів

\section{BIOLOGICAL AGENTS AS AN OCCUPATIONAL RISIK FACTORS}

\section{Tsapko V.G., Sterenbogen M.Yu., Chudnovets A.J.}

Institute for Occupational Health of AMS of Ukraine, Kiev

Literature data are devoted to the estimation of level of potential danger for those working with biological materials - microorganisms, viruses, the protozoo, microbes - producents. The problem of systematization and classification of biological factors are considered, the ways of risk estimation of biological factors to the health of working are offered.

Key words: biological factor, risk, classification of biological agents

Поступила 05.07.2005

Контактное лицо: Цапко В.Г., Институт медицины труда АМН Украины, ул. Саксаганского, 75, Киев 01033, Украина 